Arab World English Journal (AWEJ) $2^{\text {nd }}$ Special Issue on Covid 19 Challenges January 2022 DOI: https://dx.doi.org/10.24093/awej/covid2.15

\title{
The Implementation of E-Learning to Support Learning and Teaching Foreign Language: A Case Study in Ukrainian Higher Education
}

\author{
Nataliia Tymoshchuk \\ Department of Foreign Philology and Translation \\ Vinnytsia Institute of Trade and Economics of Kyiv National University of Trade and \\ Economics, Vinnytsia, Ukraine \\ Email: redish_fox15@ukr.net
}

Received: 9/14/2021

Accepted:12/24/2021

Published:1/24/2022

\begin{abstract}
The research paper examines current tendencies in implementing e-learning as an integral part of the educational process, particularly in foreign language learning in higher education. The scholar attempts to answer the following question: How can e-learning contribute to effective foreign language learning? We have identified how e-learning is applied, the different existing elearning strategies students prefer to learn with, and the extent to which learners are satisfied with the support offered by e-learning to assist the process of foreign language learning. The study is significant because understanding the learners' preferences and support of these updated methods would help to find effective teaching practices within e-learning, fostering student-centered approaches. The contribution of this research is to estimate the new experiences of university students due to e-learning implementation. We used a quantitative method to collect research data by online tools (Google forms). It was achieved due to analyzing responses to the survey-based questionnaire of 35 learners of Vinnytsia Institute of Trade and Economics of Kyiv National University of Trade and Economics, Ukraine. Within our research, we have found out that students usually use e-learning as it helps them to develop lots of soft skills besides the four basic language skills. It has also been proved that students are delighted with the e-learning application. We concluded that e-learning is an effective and innovative educational technology that can improve both the teaching and learning process in educational institutions.

Keywords: case study, e-learning, e-learning tools, foreign language, Ukrainian higher education
\end{abstract}

Cite as: Tymoshchuk, N. (2022). The Implementation of E-Learning to Support Learning and Teaching Foreign Language: a Case Study in Ukrainian Higher Education. Arab World English Journal (AWEJ) $2^{\text {nd }}$ Special Issue on Covid 19 Challenges (2) 233-244.

DOI: https://dx.doi.org/10.24093/awej/covid2.15 


\section{Introduction}

Foreign languages have been taught without computers and the Internet worldwide for ages. Teachers have been actively using chalk, boards, and markers, and their physical presence at the lesson has been inseparable from the notion of education. However, growth and technological progress have drastically affected teaching methods. The role of digital resources and interactive techniques in teaching has increased recently. Implementation of up-to-date educational digital forms and electronic didactic tools make the learning far more effective. The Internet has become one of the most important sources for obtaining and distributing information for teachers and learners.

Today, online teaching is necessary because the deadly disease Covid-19 has shaken the entire world. Lots of students study online; blended learning is also widely used. Traditional education has been replaced by the so-called digital one utilizing the convenience and popularity of the Internet. Thus, technologies have become an integral part of teaching and learning, and they have revolutionized our lives. The Internet let the Universities teach in the ongoing global pandemic of coronavirus disease. The rationale of the study comes from it focusing on students' experiences during the pandemic.

E-learning as an instrument used in higher education to foreign language learning evolved from an optional technique to an indispensable tool. The higher education system in Ukraine is experiencing some constructive changes since its traditional model does not meet the current needs of society. The COVID-19 pandemic has caused the transfer to e-learning (Ivanytska, Dovhan, Tymoshchuk, Osaulchyk \& Havryliuk, 2021). This article intends to analyze e-learning applications in foreign language learning in Ukrainian higher education, researching standard methods used in foreign language learning and the student's attitude towards them and their impact on language learning. The significance of this study is that understanding the learners' preferences and support of these up-dated methods would help to find effective teaching practices within e-learning, fostering student-centered approaches.

Our study aims to analyze e-learning application in foreign language learning in Ukrainian higher education, research standard techniques used in foreign language learning and the student's attitude towards them, and their impact on language learning. The following research questions guide this study: 1 . Are the students motivated to learn a foreign language using e-learning strategies? 2. Can e-learning strategies improve students' learning performance and motivation, making them more involved and interested in the educational process? 3 . What e-learning strategies did learners use? 4. How can e-learning contribute to effective foreign language learning? 5. What is the students' attitude towards e-learning application in foreign language learning?

\section{Literature Review}

Modern academic and scientific publications represent lots of e-learning definitions, but it is controversial to find a common one as they emphasize its various elements. Thus, Sangrà, Vlachopoulos, and Cabrera (2012) described four categories of purposes, i.e., 1) technologydriven, 2) delivery-system-oriented, 3) communication-oriented, and 4) educational-paradigm oriented. 
The first category mainly includes definitions emphasizing the technological characteristics of e-learning while presenting its other aspects as secondary ones. They interpret e-learning as the technology application for learning, e.g., Guri-Rosenblit (2005) has characterized e-learning as "the use of electronic media for a variety of learning purposes that range from add-on functions in conventional classrooms to full substitution for the face-to-face meetings by online encounters" (p. 469).

Delivery-system-oriented definitions present e-learning as a method of accessing knowledge via learning, teaching, or training. Thus, they focus on the accessibility of resources, not considering the results of any achievements. For example, Koohang and Harman (2005) consider e-learning to be "the delivery of education (all activities relevant to instructing, teaching, and learning) through various electronic media" (p. 77).

The third category (communication-oriented) investigates e-learning as a communication, interaction, and collaboration tool. According to Bermejo (2005), e-learning is education through computerized communication systems as an environment for communication, information exchange, and interaction between students and tutors. We consider Bermejo's definition as a representative sample of a communication-oriented one.

The last category of definitions (educational-paradigm-oriented) describes e-learning as a new learning approach or an improvement on an existing didactic paradigm. For instance, "elearning is the use of new multimedia technologies and the Internet to improve the quality of learning by facilitating access to resources and services, as well as remote exchange and collaboration" (Alonso, López, Manrique, \& Viñes, p. 218).

There is no face-to-face interaction between teacher and student in e-learning. Reviewing the literature, we have found that the Internet acts as an intermediate between tutor and learner, providing flexibility for learning and teaching. Some scholars believe that the development of the Internet has turned distance learning into e-learning. These terms are often considered to have the same meaning. In our opinion, distance learning and e-learning are two distinct and separate teaching techniques with similar characteristics. Bates (2005), explaining the difference between e-learning and online, stated that e-learning could encompass any form of telecommunications and computer-based learning, while online learning means using specifically the Internet and the Web. Thus, Bates (2005) has emphasized that e-learning implies the application of computers or other means of communication technologies for learning purposes. In contrast, online learning is defined as knowing where the Internet is applied.

E-learning as an instrument used in higher education to foreign language learning evolved from an optional technique to an indispensable tool. Indeed, its adoption at higher educational institutions has several benefits. Many researchers and scientists have considered the advantages of e-learning technologies adoption into education, particularly in higher schools. Analyzing the e-learning advantages gathered from the literature review, we should mention its flexibility when every student can choose the place and time suiting them; it considers the individual learners' differences allowing self-pacing; it also motivates students to interact with others exchanging and respecting the different point of views. 
According to Akturk and Gulsecen (2017), e-learning positively affects language study outcomes. Scholars focus on the unquestionable significance of distance language learning programs as they allow the learners to develop and enhance the four language skills, i.e., reading, listening, writing, and speaking. They are convinced that listening to records is far more critical and influential than text reading. An excellent combination of both activities is still a much more reliable learning technique as listening is one of the essential components in language learning. Cai (2012) has proved that e-learning improves both teaching and learning efficiency liberating the heavy labor of teachers and enabling students to master English as soon as possible. According to Chinese scientists, e-learning turns the pedagogical strategies to be studentcentered ones, focusing on improving listening comprehension and ability of expression. Thus, language acquisition depends on the student's constant practice. Therefore, e-learning counts lots of advantages in terms of foreign language learning.

However, some scientists have also named lots of e-learning drawbacks. They consider getting only theoretical knowledge the most crucial disadvantage of e-learning. As a result, learners have learned without applied practical skills (Maatuk, Elberkawi, Aljawarneh, et al., 2021). According to Arkorful and Abaidoo (2014), not all fields or disciplines can employ elearning in education. The scholars have argued this technique is more appropriate in social science and humanities.

The other obstacle for e-learning is the absence of personal interaction between learners and educators. According to Solak and Cakir (2015), "the application of distance learning system to foreign language teaching is a great challenge because the greatest problem is the lack of faceto-face communication among peers and their teachers" (p. 109). However, other scholars are convinced this direct interaction can be easily provided by different telecommunication tools allowing students to keep in touch with their teachers (Laachir, 2019). Mohammadi, Ghorbani, and Hamidi (2011) have mentioned that some people are not capable of using technology effectively, which hinders its importance in learning. Thus, it is obligatory to have the adequate technical knowledge to use the technological devices correctly during e-learning; the lack of this knowledge may negatively affect the learning outcomes.

In times of pandemic, many researchers devoted their works to EFL e-learning and its peculiarities because nowadays, it has become an integral part of the educational system (Alsuhaibani, 2021; Alwazna, 2021; Mahyoob, 2020;). Some papers have also focused on the learners' attitudes towards distance EFL e-learning. Therefore, Benadla and Hadji (2021) investigated the affective attitudes of EFL students towards distance learning assisted with Moodle Platform during the Coronavirus; Layali and Al-Shlowiy (2020) analyzed students' perceptions of e-learning for ESL/EFL, benefits of e-learning for ESL/EFL, and drawbacks of elearning for ESL/EFL in Saudi universities; Sinaga and Pustika (2021) explored the attitude of vocational high school student's understudies toward the execution of Moodle as cooperative learning in learning an English subject during the Covid-19 pandemic.

The researchers argue that "e-learning is considered as an applicable approach in EFL education that enhances reliable language practices, motivates the learners and teachers, provides the opportunity of anywhere and anytime education, and reduces the students' anxiety and costs." (Rahim \& Chandran, 2021, p. 63). Unfortunately, Ukrainian scholars have done very few e-learning applications for teaching English as a foreign language. Insufficient research on e- 
learning in foreign languages and learners' attitudes towards it in Ukrainian universities has led to the choice of the research topic.

\section{Methods}

We have used theoretical methods to analyze scientific literature on teaching English as a foreign language (EFL), e-learning, distance learning and teaching, advantages and disadvantages of e-learning. The scientific information was obtained from authentic websites, research articles, and official reports. The descriptive-analytical method was also used for our study. An online survey was conducted at Vinnytsia Institute of Trade and Economics, which is a regional subdivision of Kyiv National University of Trade and Economics, one of the most potent educational institutions of Ukraine, in May 2021. We used online tools and techniques to obtain data and analyzed it using computer-aided software, and the results of the study were interpreted using texts and numerical information.

\section{Participants}

The study population was selected in a non-probabilistic way. The first-, and second-year students of the Vinnytsia Institute of Trade and Economics of Kyiv National University of Trade and Economics (VITE KNUTE, Ukraine) were under the research. Their total number was 35 students (Philology, Germanic languages, and literature (including translation), first foreign language - English).

\section{Research Procedures}

We have used a questionnaire to collect quantitative data. It was created using Google Forms and sent private messages using Viber Messenger to get as many responses as possible. Firstly, we have collected some demographic information, the respondents were required to determine their gender (Male / Female) and age choosing one of the six available choices: "18", "19", "20", "21", "22", and "23". Other questions were related to applying electronic tools aimed at foreign language learning (English). The choices differ depending on their nature and requirements. We measured some questions using a Likert-scale survey, we had either the four items, i.e., "always", "usually", "sometimes" and "never" or the items related to the learner's agreement, i.e., "strongly agree", "agree", "disagree", and "strongly disagree". Some other questions enable the students to choose more than one option. We mean questions investigating the different language skills developed by e-learning during the process of foreign language learning. The questionnaire has been created, using Google Forms, and administered online in a randomized and equal way to the students of VITE KNUTE.

\section{Results}

This section presents the findings of the gathered data and the obtained results analysis.

Figure one represents the percentage of participants' gender; the participation of Females and Males in the questionnaire is not equal, with a difference of $60 \%$ in favor of females. However, this figure corresponds to the contingent of students majoring in philology. 

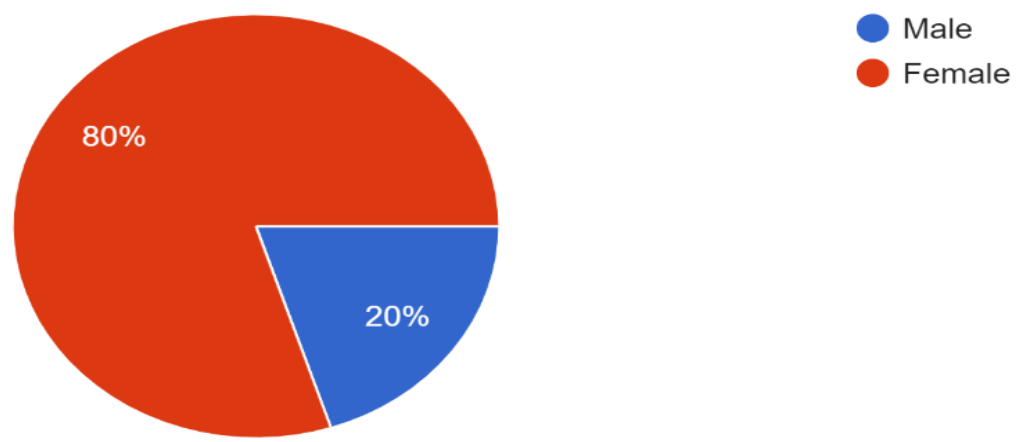

Female

Figure 1. Percentage of participants' gender

We also asked the students about their age. The most significant part of the participants is aged 18 , with 13 , ratings $37.1 \%$ of the population. Those who are aged 19 got the total number of 10 and scored the percentage of $28.6 \%$, nine twenty-years-old students $(25.7 \%)$ took part in the survey whereas only three participants $(8,7 \%)$ were older than 20 (Figure two).

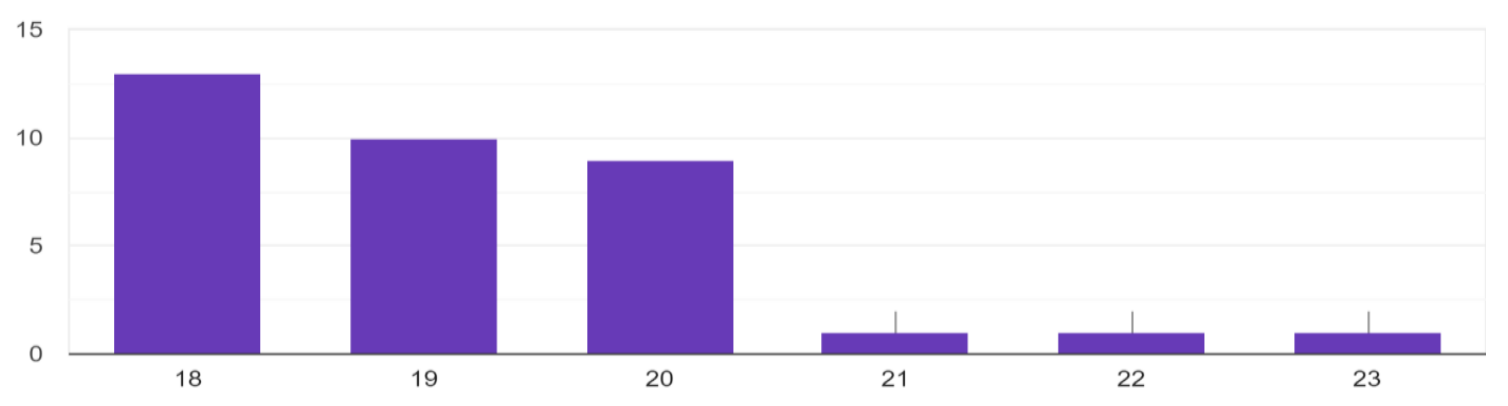

Figure 2. Percentage of participants' age

Thirty-five respondents (100\%) have answered that they use electronic tools for learning purposes. The majority of students $(51.4 \%)$ have claimed that they sometimes use electronic means for learning purposes. The total percentage of those who claimed to always use e-tools for learning goals is $45.7 \%$. Amazingly, only one participant has chosen the item "Usually". These results indicate that e-tools are frequently used by learners to facilitate their learning process (Figure three).

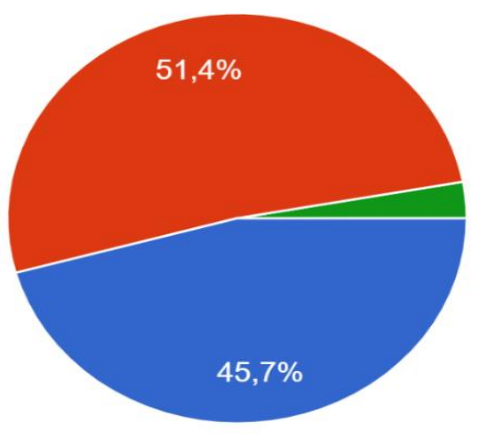

Usually

Figure 3. E-learning tools usefulness 
Figure four shows respondents' answers whether learning via e-tools is comfortable. The item "Sometimes" has taken the most significant part with a total of 20 participants and at the percentage of $57.1 \%$ of the population, followed by the item "Always" with a total of 9 students (25.7\%). The least scored thing is "Usually", with a $17.1 \%$ percentage. The obtained data indicate that learning via e-tools is considered comfortable.

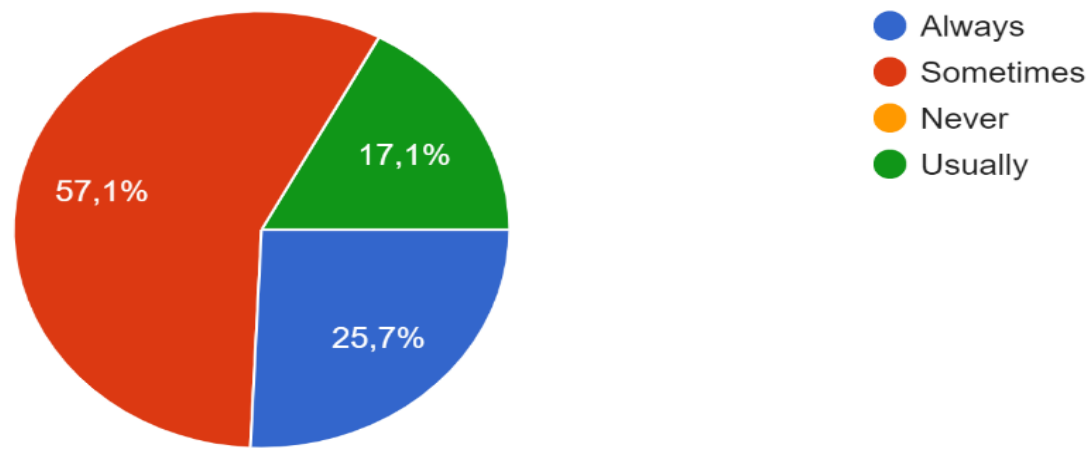

Figure 4. E-learning convenience

Figure five demonstrates the students' responses if they enjoy being online learners. Participants had choices ranging from "Always" to "Never." Sixteen of the respondents who ticked 'Always' constitute $45.7 \%$ of the population; $15(42.9 \%)$ of them indicate that they sometimes enjoy learning online; three $(8.6 \%)$ of the respondents' choice went to the option "Usually" whereas only one respondent has claimed that they never enjoy learning online with a total of $2.9 \%$.
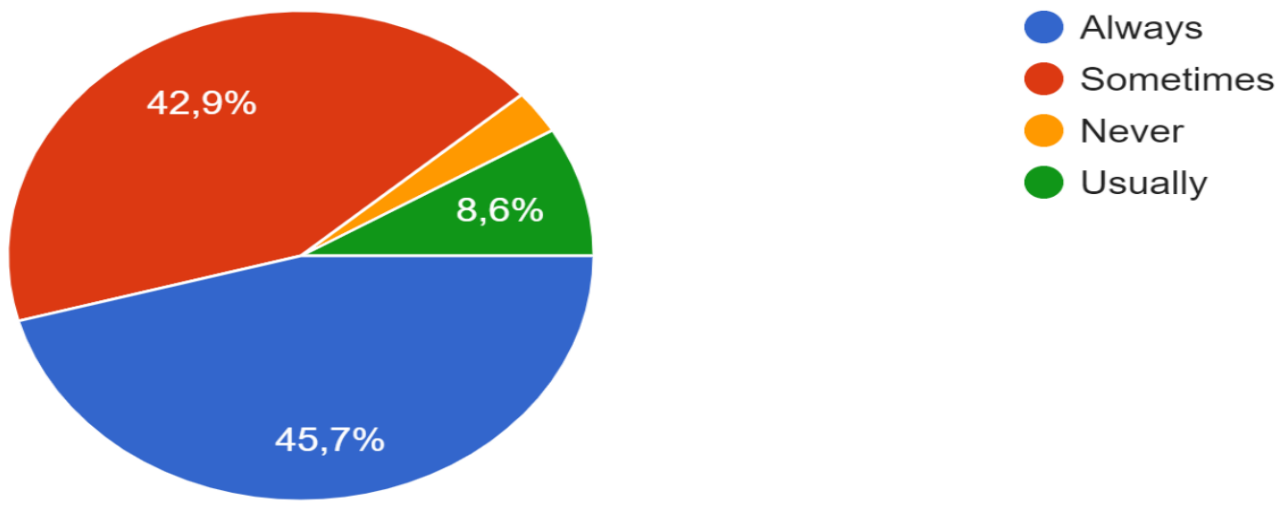

Figure 5. E-learning enjoyableness

According to Figure six data, $14(40 \%)$ students have ticked "No" as they prefer traditional learning strategies over e-learning. Ten $(28.6 \%)$ respondents could not choose between the two options and have explained that both approaches are crucial. Seven respondents representing $20 \%$ of the population said that sometimes they prefer e-learning to traditional ways of learning. Four respondents have ticked "Yes", answering if online knowledge is preferable to conventional education. 

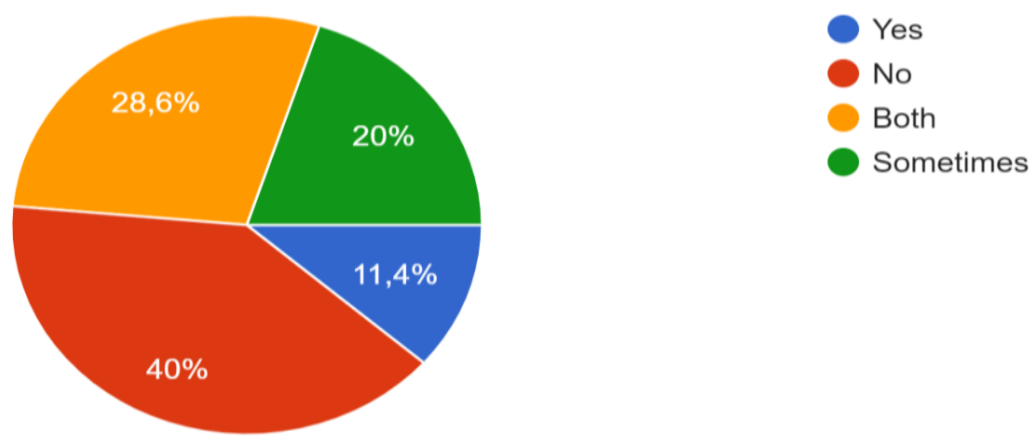

Figure 6. Online learning is preferable to traditional learning

According to figure seven, the items "Agree" and "Strongly Agree" were the most frequent responses that scored the percentages of $71.4 \%$ and $20 \%$, respectfully. However, three respondents $(8.6 \%)$ disagreed that e-learning is an essential means of foreign language learning. It indicates that e-learning is significantly adapted by the learners due to its importance in improving the quality of foreign language learning.
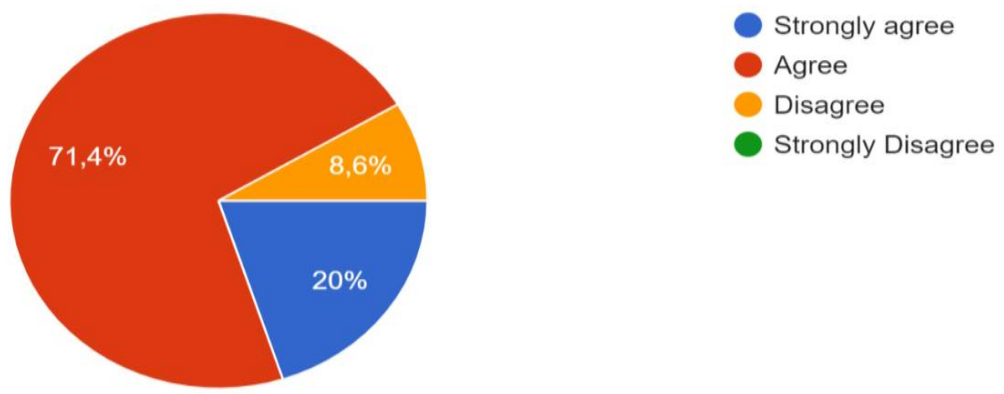

Figure 7. E-learning is an essential means of Foreign Language Learning

Multiple items were raised to investigate the e-learning techniques used by learners during English as a foreign language learning. This section enables the participant to select as many items as they need. According to Table one data, social media ranked first with a total of 28 respondents $(80 \%)$, followed by collaborative learning, with 25 respondents representing $71.4 \%$ of the population. Twenty respondents $(57.1 \%)$ went for the game-based education, and 17 students $(48,6 \%)$ were for video conferencing, and virtual classes, and simple e-learning resources (e-lessons or online books). E-learning communities or websites are the least used elearning technique by the participants.

Table 1. E-learning methods online EFL learners use

E-learning techniques used by EFL learner

Social media

Collaborative learning (blogs, chats, online discussions)

Game-based learning

Video conferences/Virtual classes

Simple E-learning resources (E-lessons or online books)

E-learning communities or websites (Khan Academy, Coursera, TedEd)

\begin{tabular}{|c|c|}
\hline Frequency & Percentage \\
\hline 28 & $80 \%$ \\
\hline 25 & $71.4 \%$ \\
\hline 20 & $57.1 \%$ \\
\hline 17 & $48.6 \%$ \\
\hline 17 & $48.6 \%$ \\
\hline 12 & $34.3 \%$ \\
\hline
\end{tabular}


The next question that participants had to respond to was also with multiple choices, and it aims at investigating e-learning contribution to effective foreign language learning. According to collect quantitative data (Table two), the two items have been selected the most (with 19 respondents for each), one thing was related to necessary thinking skills where respondents have noted that e-learning has enabled them to develop their critical thinking skills, the other item was that e-learning has helped them expand their vocabulary and enhance their writing skills. 17 respondents $(48.6 \%)$ have admitted the possibility for the learners to learn anytime and anywhere as long as they hold the excellent technological material. The item that investigates whether e-learning allows the learners to be engaged easily in language knowledge and enjoyably gain information was also an option selected by $42.9 \%$ of respondents (15 students). Ten students $(28.6 \%)$ mentioned about the positive impact of e-learning on their communication skills. $25.7 \%$ (nine students) have agreed that e-learning has helped them improve their pronunciation in effortless ways. The next item related to the role of e-learning in developing problem-solving skills was selected by $17.1 \%$ of the respondents (six students). The last option was "None of these", which was chosen by three respondents out of $35(8.6 \%)$.

Table 2. E-learning contribution to effective foreign language learning

\begin{tabular}{|l|c|c|}
\hline Statement & Frequency & Percentage \\
\hline $\begin{array}{l}\text { By using E-learning, I could quickly develop critical thinking skills. } \\
\begin{array}{l}\text { By E-learning, I could expand my vocabulary and enhance my writing } \\
\text { skills. }\end{array}\end{array}$ & 19 & $54.3 \%$ \\
\hline $\begin{array}{l}\text { It enabled me to access information and knowledge whenever \& wherever I } \\
\text { was. }\end{array}$ & 17 & $48.6 \%$ \\
\hline $\begin{array}{l}\text { It enabled me to engage in knowledge easily and enjoyable gain } \\
\text { information. }\end{array}$ & 15 & $42.9 \%$ \\
\hline $\begin{array}{l}\text { It helped me to improve my communication skills. } \\
\text { My pronunciation has much improved in effortless ways. }\end{array}$ & 10 & $28.6 \%$ \\
\hline $\begin{array}{l}\text { E-learning has helped me to improve my problem-solving skills. } \\
\text { None of these }\end{array}$ & 6 & $25.7 \%$ \\
\hline
\end{tabular}

The last question was aimed to measure the students' satisfaction with the e-learning application in foreign language learning. According to research data (Figure eight), $71.4 \%$ (25 participants) of the population are confident with e-learning. $22.9 \%$ of the respondents (eight students) have expressed the highest level of satisfaction. In contrast, only two participants (3.7\%) out of 35 have expressed their dissatisfaction with e-learning in improving their foreign language learning level.

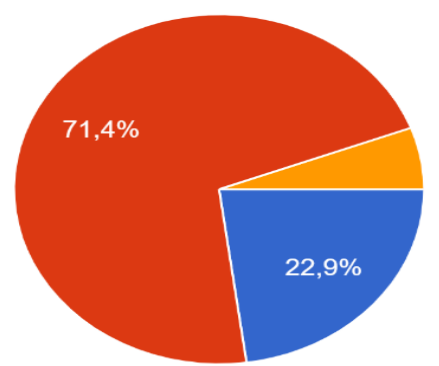

Very satisfied

Satisfied

Unsatisfied

Figure 8. Students' satisfaction with the e-learning application in language learning 


\section{Discussion}

We have found that students consider e-learning an essential and enjoyable way of learning; they also prefer it over traditional education. Many students are convinced e-learning is a vital means of foreign language mastering. According to the respondents' answers survey, elearning is both valuable and practical learning tool because it allows them to be comfortable during learning as virtual learning environments enable learners to continue their study at their own pace and time. The learners have also noticed that they use diverse strategies varying from simple resources to more complicated ones. The e-books, social media, virtual classes, virtual conferences, e-learning communities, and websites, as well as collaborative learning using forums, chats, and online discussions, have been applied. Analyzing e-learning contribution to foreign language learning, students have mentioned many skills they could improve, i.e., critical thinking, problem-solving, communication, and writing skills. They have also developed their pronunciation by watching videos and hearing native speakers' pronunciation and expanding their vocabulary knowledge.

The last question of the questionnaire (Are you satisfied with the use of e-learning in language learning?) was used to provide objective scientific data. Thus, students are primarily confident with e-learning in foreign language learning which responds ideally to the question related to students' attitudes. Using technology for teaching and learning has become part and parcel for students.

These results coincide with those obtained in similar research by Rahim and Chandran (2021). They also agree with Layali and Al-Shlowiy (2020) as students' perceptions were in favor of e-learning for ESL/EFL universities, "the researchers call for its adoption as the only viable means of learning, with documented benefits and marginal drawbacks, that is favored by students at such world pandemic's time" (p. 106). The research conclusions align with Pylypenko and Kozub (2021), in part "the Ukrainian education system has a positive tendency of development, demonstrates readiness to distance education, and increases the level of professional and pedagogical competence of university teachers" (p. 382). Thus, e-learning suggests new ways of learning when the learner plays an active role and emphasizes independent, flexible and collaborative learning. As far as collaborative learning was mentioned, we should add that virtual classrooms help students gain a sense of collaboration and share knowledge and opinions with other students from their own country worldwide as e-learning tools have no borders.

\section{Conclusion}

The study aims to analyze e-learning application in foreign language learning in Ukrainian higher education, to research standard techniques used in foreign language learning and the student's attitude towards them, and their impact on language learning. The research has revealed the efficiency of e-learning implementation and proved it to be an innovative change in teaching and learning a foreign language in high school. The outlined methodological characteristics of e-learning are its flexibility, individualization, and differentiation of the learning process.

The study found that learners consider e-learning an essential and enjoyable way of learning; they also prefer it over traditional education. Implementation of innovative pedagogical 
technologies and techniques at the foreign language classes have increased the foreign language proficiency of students, providing the best conditions for gaining listening and reading skills, increased motivation for learning, promoted personal development of students, made the teaching process student-oriented. Analyzing e-learning contribution to foreign language learning, students have mentioned many skills they could improve, i.e., critical thinking, problem-solving, communication, and writing skills. They have also developed their pronunciation by watching videos and hearing native speakers' pronunciation and expanding their vocabulary knowledge.

E-learning forms are the most effective and farsighted method among modern learning practices. Thus, lots of Ukrainian and educational foreign institutions consider e-learning to be the first vital step to have a high education quality.

We suggest further studies to find out the teachers' views and experiences towards English language e-teaching during the pandemic.

\section{About the author:}

Nataliia Tymoshchuk Ph.D. in Philology, Associate Professor at the Department of Foreign Philology and Translation, VITE KNUTE, Vinnytsia, Ukraine. Her research interests include linguistics, e-learning, mind-mapping, flipped classroom, methodology of teaching foreign languages, blended learning. https://orcid.org/0000-0001-5638-5825

\section{References}

Alonso, F., López, G., Manrique, D., \& Viñes, J. M. (2005). An instructional model for webbased e-learning education with a blended learning process approach. British Journal of Educational Technology, 36(2), 217-235.

Alsuhaibani, Z. (2021). Saudi EFL Students' Use and Perceptions of Blackboard Before and During Online Learning amid COVID-19. Arab World English Journal (AWEJ) Special Issue on CALL (7). 22-37. DOI: https://dx.doi.org/10.24093/awej/call7.2

Alwazna, R. Y. (2021). Teaching Translation during COVID-19 Outbreak: Challenges and Discoveries. Arab World English Journal, 12 (4) 86-102. DOI: https://dx.doi.org/10.24093/awej/vol12no4.6

Arkorful, V., \& Abaido N. (2014). The role of e-learning, advantages and disadvantages of its adoption in higher education. International Journal of Education and Research, 12(2), 397-410.

Aktürk, C., \& Gulsecen, S. (2017). Foreign Language Education and E-Learning. GLOKALde, $3(1), 40-50$.

Bates, A. T. (2005). Technology, e-learning and distance education ( $2^{\text {nd }}$ ed.). Routledge. Retrieved from: https://www.amazon.com/Technology-learning-Distance-EducationRoutledge/dp/0415284376. p. 23.

Benadla, D., \&Hadji, M. (2021). EFL Students Affective Attitudes towards Distance E-Learning Based on Moodle Platform during the Covid-19the Pandemic: Perspectives from Dr. MoulayTahar University of Saida, Algeria. Arab World English Journal (AWEJ) Special Issue on Covid 19 Challenges (1). 55-67. DOI: https://dx.doi.org/10.24093/awej/covid.4

Bermejo, S. (2005). Cooperative electronic learning in virtual laboratories through forums. IEEE Transactions on Education, 48(1), 140-149. DOI: https://doi.org/10.1109/TE.2004.837045 
Arab World English Journal (AWEJ) 2nd Special Issue on Covid 19 Challenges January 2022

Cai, H. (2012). E-learning and English Teaching. IERI Procedia, 2, 841-846.

Gülseçen, S., \&Cemal, A. (2017). Foreign Language Education and E-Learning. LWT-Food Science and Technology, 3(1), 40-50.

Guri-Rosenblit, S. (2005). 'Distance education' and 'e-learning': Not the same thing. Higher Education, 49(4), 467-493. DOI: https://doi.org/10.1007/s10734-004-0040-0

Ivanytska, N., Dovhan, L., Tymoshchuk, N., Osaulchyk, O.,\& Havryliuk, N. (2021). Assessment of Flipped Learning as an Innovative Method of Teaching English: A Case Study. Arab World English Journal, 12 (4), 476-486. DOI: https://dx.doi.org/10.24093/awej/vol12no4.31

Koohang, A., \& Harman, K. (2005). Open source: A metaphor for e-learning. Informing Science Journal, 8, 75-86.

Laachir, A. (2019). The Implementation of Collaborative Learning via Virtual Communities in Moroccan Higher Education. International Journal of Language and Literary Studies, 1(2), 60-73. DOI: https://doi.org/10.36892/ijlls.v1i2.28

Layali, K., \& Al-Shlowiy, A. (2020). Students' perceptions of e-learning for ESL/EFL in Saudi universities at time of coronavirus: A literature review. Indonesian EFL Journal, 6(2), 97- 108. DOI: https://doi.org/10.25134/ieflj.v6i2.3378.

Maatuk, A.M., Elberkawi, E.K., Aljawarneh, S. et al. (2021). The COVID-19 pandemic and Elearning: challenges and opportunities from the perspective of students and instructors. Journal of Computing in Higher Education. DOI: https://doi.org/10.1007/s12528-021-09274-2

Mahyoob, M. (2020). Challenges of e-Learning during the COVID-19 Pandemic Experienced by EFL Learners. Arab World English Journal, 11 (4) 351-362. DOI: https://dx.doi.org/10.24093/awej/vol11no4.23

Mohammadi, N., Ghorbani, V., \& Hamidi, F. (2011). Effects of e-learning on language learning. Procedia Computer Science, 3, 464-468

Pylypenko, O., \& Kozub, L. (2021). Foreign Language Teaching of Ukrainian University Students in a Distance Learning Environment. Arab World English Journal, 12 (3), 375384. DOI: https://dx.doi.org/10.24093/awej/vol12no3.26

Rahim, M. N., \& Chandran, S. S. C. (2021). Investigating EFL Students' Perceptions on Elearning Paradigm-Shift During Covid-19 Pandemic. Elsya : Journal of English Language Studies, 3(1), 56-66. https://doi.org/10.31849/elsya.v3i1.5949

Sangrà, A., Vlachopoulos, D., \& Cabrera, N. (2012). Building an Inclusive Definition of ELearning: An Approach to the Conceptual Framework. International Review of Research in Open and Distance Learning, 13, 145-159.

Sinaga, R. R. F. \& Pustika, R. (2021). Exploring Students' Attitude towards English Online Learning Using Moodle during Covid-19 Pandemic at SMK Yadika Bandar Lampung. Journal of English Language Teaching and Learning, 2(1), 8-15.

Solak, E., \& Cakir, R. (2015). Language learning strategies of language e-learners in Turkey. ELearning and Digital Media, 12 (1), 107-120. DOI: https://doi.org/10.1177/2042753014558384 